\title{
Migrant Workers' Village as an Effort to Strengthen The Rights of Indonesian Migrant Workers
}

\author{
Devi Rahayu, ${ }^{1, *}$ \\ ${ }^{1}$ Faculty of Law, University of Trunojoyo Madura, Bangkalan, Indonesia
}

\begin{abstract}
Many problems faced by Indonesian migrant workers and a comprehensive protection are the reason for the government to ratify Law No. 18 year 2017, The Protection of Indonesian Migrant Workers. The regulation provides protection by not only the central government, local government but also village government. It is expected to provide protection in pre-departure stage, during or after placement. The existence of village of migrant workers which has protection for migrant workers by: doing procedural administration, strengthening migrant workers' rights, empowering migrant workers. The strengthening of the rights of migrant workers is done by conducting socialization, training of case and studying the regulations of the destination country. By strengthening the rights of migrant workers, it is expected that migrant workers understand their rights, know what they are doing when they are experiencing problems and understand the rules. It is expected that with a pre-procedural placement process and readiness to understand the rights of migrant workers, it can prevent the occurrence of cases while working in the destination country.
\end{abstract}

\section{Introduction}

The procedure of sending migrant workers includes pre, during and post placement. In those three stages, the migrant workers are vulnerable to be the victims and belong to unsafe migration. From pre placement stage: the absence of data in the workers' area, irrelevant identity, illegal middlemen, debt, inhumane shelter conditions, fraud, and violent acts. During placement: inhumane working conditions, violence, unpaid salary, long working hours, unfitted work, working accidents and death. Post placement: extortion, usurpation, fraud. Most problems are experienced during placement because of "irregularities" in pre placement and procedural processes. Therefore, it is crucial to break the chain of unsecure migration starts from the village.

The enactment of law No. 18 year 2017 on the Protection of Indonesia Migrant Workers provides better arrangements and the guarantee of migrant workers' right. The PPMI (Indonesian Migrant Worker Protection) law explains more detailed about the liability

* Corresponding author: rahayudevi78@yahoo.com 
protection carried out by the Government; central, provincial, subdistrict and village government. The protection arrangements by village government is relatively new policy. It is regulated in article 42 of PPMI law, where the village government has the obligation to: provide job information, verify data, facilitate administration requirements, monitor the departure and return also the candidates empowerment, workers and migrant workers' families. Before the responsibilities of the village government exist, there have been some efforts made by civil society to initiate the formation of migrant workers village in some areas.

The Government responsibility to provide protection for migrant workers should be responded positively, because the problems starts from the initial procedure in the village. By providing information about migrant workers' right, they are expected to have good understanding of rules and information when facing problems. Strengthening the rights of migrant workers is done in the village on the early stages of the pre departure. The problems are the absence of data in the village. Consequently, it will be hard if Central Government, in practice, does not mentor the activity, [1] so the arrangements of migrant worker protection law remains zero implementation.

The guarantee to fulfill the rights of Indonesian migrant workers in the process of migration has been regulated in law No. 6 year 2012, which ratifies the International Convention on the Protection of All the rights of migrant workers and their Families [2] which then used as the basis of PPMI law. Starting fortifying the rights of migrant workers in the village will let migrant workers understand their rights and how to fight for it.

\subsection{Construction of Human Rights for migrant workers}

The definition of human rights concerns something fundamentally important, was equally owned by all people, without conditions, and cannot be tempered. The question related to human rights itself is a where it is actually the right goes. All rights are classed into natural rights in various manifesto [3].

Working is one form of human rights. This is fit with the provisions of the United Nations Universal Declaration of Human Right year 1948 article 23 which generally states that everyone has right to work [4] and in article 6 of International Covenant on Economic, Social and Cultural Rights (ICESCR) 1996 [5]. While the Foundation of everyone's right to do the migration is set in article 13 (1)"everyone has the right to freedom of movement and residence within the borders of each state"[6].

Right to work is guaranteed in 1945 Constitution (Amendment) section 28 D (2) which States "everyone has the right to work and got rewards and decent and fair treatment in employment relationships". The guarantee of right to work in 1945 Constitution surely brings consequences for the State to provide legal protection to the citizens. Furthermore, in article 281 (4) States "the protection, promotion, enforcement and the fulfillment of human rights is the responsibility of the country especially the Government".

Law No. 6 year 2012 which ratify the International Convention on the Protection of All the rights of migrant workers and their Families states that people who qualify as a migrant workers based on its provisions, has the right to accept any human rights regardless their legal status. This Convention applies to all migrant workers and members of their families, regardless gender, race, skin colour, language, religion, political opinion or any opinion. Its protection includes all processes of migration before departure, transit, live, work, and return to areas of origin.

Part IV of the convention sets a number of obligations on States parties with the intention of advancing the good conditions, equivalent, humane and based on international migration law for migrant workers and members of their families. This requirement 
includes immigration policy making, exchange of information with other States parties, the provisions concerning information on employers, workers and their organization about policies, laws and regulations; and assistance on migrant workers and their family members.

\subsection{Development and empowerment of village community}

The construction of community began emerging around 1980s when there is critics of development that does not involve community participation [7]. By that time the concept of welfare State is criticized because the failure to provide prosperity in society. The main weakness lies in the role of the State, which is so dominant that can stop the role of other two stakeholders, i.e., the private sector and the community. The grant of power in local initiatives and community participation becomes a keyword in community development [8].

The construction of this community is to see community as a unit of work. The activities are based on local initiatives, local resources and local leadership. Community development means putting trust. This belief is expressed in form of equal opportunity, freedom of choice and empowerment. This condition will create impulse within the community to continuously establish independently. Community independence means reducing dependence on outside parties [8].

Community empowerment is the central issue in community development. Empowerment covers two aspects; to give or to give authority and to give ability to or enabling. The first sense, empowerment means giving power, divert power and delegating authority to others. Second, empowerment is defined as an attempt to give abilities or power. In this research context the empowerment is meant as an attempt to provide skills and power to community of migrant workers' village. The application of democracy aspect and participation with the focal point in the locality will be a cornerstone for strengthening efforts of local potential. At this point then community empowerment is also focused on strengthening the individual members of the community along with all aspects related [9].

\section{The Objective of the Study}

The existence of village which can give guarantee of rights for migrant workers and their family members is the goal from the villages who concern on migrant workers. In fact, not all villages are ready to do so. The focus of this paper is to expose how the process in making village as the trigger in strengthening the rights of migrant workers.

\section{Methodology}

The method used is empirically, by conducting in-depth interviews with some parties. Interviews are conducted with the Central Government, the Ministry of manpower and transmigration, NGOS and Governments. The data is analyzed descriptively.

\section{Discussion}

To make the village Government can run the liability protection, it needs the existence of migrant workers community, the active role of society and local governments. According to Suparjan [8] it is necessary to empower the villages by raising critical awareness over the position of the community in social and political structures; arrange argument against 
various kinds of exploitation and the termination; community capacity building; sociocultural development. The values in the cultural traditions of local communities are mutual and arisan can be viewed as social capital in realizing the development progress of society [2]. Empowerment is a process of learning that emphasizes the involvement of community participation.

In 2014 the migrant care has initiated migrant workers village programs (desbumi). There are 18 villages in NTT, NTB, Central Java and East Java, start to build the migration system service in the village. Such services include the provision of migration information, service of documents, the provision of the database, the complaints mechanism, economic empowerment and the regulation of the village [10]. Villages have responsibility to protect migrant workers based on PPMI act. There is difference between 18 villages initiated by migrant care and other villages in doing the responsibility because there will be burdened for other villages. Therefore, Desmigratif is given to 60 counties and 120 villages with most working abroad population. There are four main pillars that are carried by the Desmigratif; create centre of migration service, develop TKI and their families' productive efforts, facilitate the establishment of Desmigratif Learning house, and facilitate the formation of financial institutions.

The interviews conducted in Juntinyuat (Indramayu), Lipursari (Wonosabo), Nyerot (Lombok Tengah) obtained information: a third of the village originally had been initiated by Desbumi program then continued with the desmigratif program. The transition brings positive impact to the village because the process is just continuing the course. However, for the villages which just receive Desmigratif get difficulties because the lack of community awareness.

Involving community in all stages of development is important because it is more bottom up rather than top down. Urgencies of participatory approach in society development according to Diana Conyers (1954) in Suparjan are: public participation is a tool to obtain information about the conditions, needs and attitudes of local people, community can give more trust when they are involved in development because it is part of democracy. The key activities carried out by Ngos are forming a core group of community and build community awareness, doing assessment by all stake holders of the village, the organization of communities and mentoring. Government programs are usually the Central Government determines the village which will be used as a companion program.

Desbumi and Demisgratif program have migration service for migrant workers. The migration service gives information about migration process, information of law in both Indonesia and destination country, advocacy information over the case of migrant workers and data migration. Many cases experienced by Indonesian migrant workers occurred during placement is because lack of migration process understanding, ignorance the law of the destination country, unknowing the rights of migrant workers and inability to solve problems. Placement process became the starting point of safe migration.

Act of PPMI article 6 (1) arrange the rights of migrant workers done by the village government: get appropriate job, obtain correct information about job market, placement procedures and overseas working conditions and obtain professional service. If such rights are given, migrant workers gain the right information about the job in destination country, type of work and wages, information of safe migration processes, passing on personal data correctly. Giving safe migration information and document management can avoid falsification of documents and trim the role of scalpers. Migration procedures contain information of Indonesian law rules. Working conditions are about the rules and culture of destination country. In addition, there is also advocacy training to prepare migrant workers from having problems and teach them to solve by contacting related parties.

Legal protection for workers according to Soepomo at Asikin [11] is divided into three; economic, social and technical legal protection. Economic 1 protection related with 
appropriate wages based on employment contract, social protection related to social security of migrant insurance, technical protection related to safe migration process. Information of employment contract, insurance, and the process given by village. Related to legal protection for the workers Suliati Grace also suggested that Indonesia must protect the citizens, including migrant workers [12]. Legal protection of workers, either with or without the help of the Organization of workers, through regulations, aims to protect the weaker party [12]. It means that legal protection for workers is a protection of unequal position between migrant workers and employers therefore it takes the role of Government to ensure the occurrence of it. From village government, it can provide a guarantee of protection for migrant workers and members of their families.

Strengthening the rights of migrant workers is expected to provide protection for them. Village government eventually can be independently resolve cases of their migrant workers. Either case happened in placement process, during placement, and post placement. For the cases happened during placement usually handled by doing coordination with the County, provinces, Central Government and NGO's.

When migrant workers are working in the destination country, the migrant worker's families also obtained guarantees of rights as in act PPMI article 6 (3). Families of migrant workers should have the right to obtain the conditions of migrant workers, treasure of migrant workers who died, a copy of working document. Even, the families of migrant workers also get empowering program economically so the earned money from the migrant workers can be a productive capital.

As nonprofit sustainability efforts, there should be village regulations governing the funds used to protect migrant workers and members of their families. Village fund allocation can reduce the dependence of the program cost.

\section{Conclusions}

Arranging protection responsibility by village government can support village to give protection guarantee for migrant workers and their families. However, it should consider public participation and positive response from community. The formation of migrant workers group, assessment from all stakeholders, community organization, regulations arrangement, establishment of Service Center, the empowerment of the capacity of village apparatus, preparation of institutional services and village readiness. The process is indeed time consuming but it must be done. By providing safe migration service, information about the rights of migrant workers and members of the families can be shared well.

\section{References}

1. D.Rahayu, Pengembangan Model Desa Buruh Migran Sebagai Upaya Perlindungan dan Migrasi Aman (Research Proposal, LPPM Universitas Trunojoyo Madura, 2017)

2. $\quad$ M. Care, Panduan Membangaun Desa Peduli Buruh Migran (Jakarta, 2016)

3. J. Fielberg, dalam Frans Ceunfin, Hak-hak Asasi Manusia, Pendasaran dalam Filsafat Hukum dan Filsafat Politik (Titian Galang Printika, Yogyakarta, 2008)

4. W. Laqueur, The Human Right Rider (New American Library, New York, 1979)

5. M.E. Muhtaj, Dimensi-dimensi HAM, Mengurai Hak Ekonomi Sosial dan Budaya (Raja Grafindo, Jakarta, 2009)

6. W. Laqueur, The Human Right Rider, (New American Library New York, 1979)

7. Suparjan dan H. Sunyatno, Pengembangan Masyarakat : Dari Pembangunana Sampai pemberdayaan (Aditya Media, Yogyakarta, 2004)

8. Z. Asikin, Hukum Ketenagakerjaan (Raja Grafindo Persada, Jakarta, 1993) 
9. S. Rahmat, Upaya Peningkatan Perlindungan Hukum Wanita Pekerja di Perusahaan Industri Swasta Studi Kasus tentang Wanita PekerjaHarian di Daerah KhususIbu Kota Jakarta (Disertasi Program Doktor Ilmu Hukum Universitas Indonesia, Jakarta) 